\title{
A NEW CONTROLLER FOR PHOTOVOLTAIC PANEL FED UNIFIED POWER QUALITY CONDITIONER TO POWER QUALITY IMPROVEMENT
}

\author{
Yasemin ONAL*, Department of Electrical and Electronics Engineering, Bilecik Seyh Edebali University, Turkey, \\ yasemin.onal@bilecik.edu.tr \\ (iD) https://orcid.org/0000-0003-0173-0948)
}

Received: 30.11.2020, Accepted: 25.01.2021

*Corresponding author

Research Article

DOI: $10.22531 /$ muglajsci.833386

\section{Abstract}

In this study, a new controller based on the synchronous reference frame (SRF) in a photovoltraic (PV) panel supported three-phase unified power quality conditioner ( $P V-U P Q C)$ is proposed to solve power quality problems in power systems. The serial and parallel active power filters fed with energy by PV panels are used together in the PV-UPQC system. In the proposed controller, measurement values are taken from four different points of the power system. The obtained values and $D C$ voltage generated by PV panels are used to calculate the reference current and voltage values. PWM signals of switches used in active filters are produced using moving average filter and space vector-PWM. The algorithm used in both filters consists of two parts. The first is the mppt algorithm, in which the maximum voltage is obtained from the PV panels, and the second is the SRF-based proposed algorithm, where the reference current or voltage is obtained. Simulation and experimental studies of the proposed controller are applied. When the results obtained are examined, the proposed controller for three-phase PV-UPQC gives better results than the traditional SRF based controller in attenuation of harmonics in current and voltage.

Keywords: Total harmonic distortion, Active power filter, Photovoltaic system, Moving average filter MAF, Power quality improvement.

\section{GÜÇ KALİTESİ SORUNLARINI ÇÖZMEK İÇİN FOTOVOLTAIK (PV) PANEL DESTEKLİ BİRLEŞİK GÜÇ KALITTESİ DÜZENLEYİCISİ İÇİN YENİ BİR DENETLEYİİ}

\section{Özet}

Bu çalışmada, enerji sistemlerindeki güç kalitesi sorunlarını çözmek için fotovoltaik (PV) panel destekli üç fazlı birleşik güç kalitesi düzenleyicisinde (PV-UPQC) senkron referans çerçevesine (SRF) dayanan yeni bir denetleyici önerilmiştir. PV panel sistemi tarafindan üretilen enerji ile beslenen seri ve paralel aktif güç filtreleri, PV-UPQC sisteminde birlikte kullanılmaktadır. Önerilen denetleyicide, güç sisteminin dört farklı noktasından ölçüm değerleri alınır. Elde edilen değerler ve PV paneller tarafından üretilen DC gerilim, referans akım ve gerilim değerlerinin hesaplanmasında kullanılmaktadır. Aktif filtrelerde kullanılan anahtarların PWM sinyalleri hareketli ortalama filtre ve uzay vektör-PWM yöntemleri kullanılarak üretilmektedir. Her iki filtrede de kullanılan algoritma iki bölümden oluşmaktadır. Birincisi, maksimum gerilimin PV panellerinden elde edildiği mppt algoritması ve ikincisi, referans akımın veya gerilimin elde edildiği SRF tabanlı önerilen denetleyici algoritmasıdır. Önerilen denetleyicinin simülasyon ve deneysel çalışmaları yapılmıştır. Elde edilen sonuçlar incelendiğinde, üç fazlı PV-UPQC için önerilen denetleyici, akım ve gerilimdeki harmoniklerin azaltılmasında geleneksel SRF tabanlı denetleyiciden daha iyi sonuçlar vermektedir.

Anahtar Kelimeler: Toplam harmonik bozulma, Aktif güç filtresi, Fotovoltaik sistem, Hareketli ortalama filtre HOF, Güç kalitesi.

Cite

Onal, Y., (2021). “A New Controller for Photovoltaic Panel Fed Unified Power Quality Conditioner to Power Quality Improvement", Mugla Journal of Science and Technology, 7(1), 14-24.

\section{Introduction}

Solar energy has been preferred more than fossil energy in recent years because it does not cause air pollution, is not a costly energy and is not a depleted energy source. Photovoltaic (PV) panels consisting of serial and parallel connected cells are devices used to convert solar energy into electrical energy [1].

Today, energy quality has become an important factor with the usage of advanced devices. The current and voltage harmonics occur in the power system with the increasing use of nonlinear power electronics circuits. 
The voltage unbalance, voltage sags and swells, harmonics in current and voltage are some examples to the problems created by power quality. They may damage the sensitive equipment, cause the loss in efficiency of electrical machines, turn on the contactor relay, or over heat the cables [2]. Thyristor switched capacitors and passive LC filters are used to enhance the power factor of AC loads and reduce the harmonics in voltage and current. Such devices have some disadvantages such as having constant resonance, large circuit structures, high costs and adjustment problem. Active power filters (APF) and unified power quality conditioner (PV-UPQC) with DC source fed by PV panels have been developed by the operation of active switches at very high frequencies. APF allows to suppress the harmonics in voltage and current with high frequency, perform reactive power compensation, eliminate some unbalances in three-phase systems and reduce neutral line currents [3].

Recently, there are many control algorithms applied to the PV-UPQC system to improve power quality. These algorithms are implemented as a function of time and frequency. Control algorithm applied as a function of time is used more widely because calculations are not complicated and there is no delay in time. The control algorithms frequently used for the PV-UPQC system in the literature are the $P Q$ algorithm called instantaneous active and reactive power algorithm[4-7] and synchronous reference frame (SRF) algorithm [8-11]. However, better results are obtained by using the SRF control algorithm when compared to other algorithms in eliminating power quality problems. In the SRF control algorithm, the measured current or voltage signals are passed through the low pass filter and the high pass filter to obtain reference current and voltage information used in active switches[10]. The other control algorithms used for PV-UPQC in the literature are sliding mode controller (SMC) [12], high selectivity filter (HSF) [13], fuzzy logic controller [14], the instantaneous sequence component theory (ISCT) [15], instantaneous power control[16], the unit vector template technique [17-18], the hysteresis and boundary control [19] and power angle control [20].

The moving average filter (MAF) is used by [21] and [22] in the literature. In the study, the load currents and voltages are measured in the series-APF (S-APF) and parallel-APF (P-APF). The source current is controlled in the S-APF using MAF and the grid voltage is controlled with the and MAF isn't used to control the P-APF [21]. The load currents are measured in the P-APF and the reference currents are obtained from output a MAF. The switching signals are obtained using hysteresis-PWM (H-PWM) technique. In the S-APF, the load voltages are used and these signals are passed through a sinusoidal PWM voltage controller and MAF isn't used [22]. In the proposed study, a new SRF based control algorithm has been developed which uses MAF and space vector-PWM technique to improve power quality in three phase series and parallel active power filter fed by the PV panel. In the controller used in P-APF, only ab source currents are measured and $c$ source current is calculated using two measured currents. The d-q components are calculated using abc 3 phase currents. MAF filter is used to obtain the reference current signals. The reference source currents are compared with the sensed source current and the switching signals are obtained using space vector-PWM technique. In the controller used in S-APF, only ab source voltages are measured and c source voltage is calculated using two measured currents. The $\mathrm{d}-\mathrm{q}$ components are calculated using abc 3 phase voltages. MAF filter is used to obtain the reference load voltage signals. The obtained reference load voltages are compared with the sensed load voltages and the switching signals are obtained using space vector-PWM technique.

The main advantages of the proposed control method are as follows:

1) reduced THD by using DC voltage produced by PV panels.

2) improved power factor;

3) improved source current compensation due to use of MAF in d-q control of UPQC;

4) improved source voltage compensation due to use of MAF in d-q control of UPQC;

5) reduced the numbers of measurements.

In the study, the number of measurements has been reduced by using only source currents, voltages and DC voltage and the operation of the controller has been improved. The DC voltage produced using PV panels is converted to AC voltage through P-APF using the MPPT method and transferred to the energy system. Thus the harmonic of current is corrected by the PV current transferred to the grid. The performance of the controller is analyzed under balanced and unbalanced nonlinear RL load or RC load conditions. Analysis studies are carried out in the PSIM program and the numerical results obtained were compared with other algorithms in the literature.

\section{Theoretical Part}

\subsection{The Determination of Switching Signals Using Space Vector PWM}

The space vector-PWM technique is based on the conversion of three phase voltage vectors of the synchronous machine into a single rotating vector. In space vector-PWM technique, it is desired to obtain a voltage signal in sinus form where switching loss and total harmonic distortion value is low. To accomplish this, a switching vector indicating the switching states of the active switches used in S-APF and P-APF, and different sequences of this vector are used. The most correct switching sequence is chosen from these vectors. In the space vector-PWM technique, no 
comparison is made with the triangular signal in obtaining the PWM signals of the switches. The activation and deactivation times of the switches are obtained numerically. The space vector-PWM is used to obtain a three-phase voltage signal at the desired amplitude and phase at the inverter output from a constant DC voltage. This three-phase voltage signal is shown using the space vector [23]. Using the space vector-PWM technique, harmonics and THD are reduced and a better output voltage is provided. The $d-q$ vector coordinates of the space vector-PWM are shown in Figure 1 . The abc voltages are calculated using $(1,2)$ the d-q components.

$V_{d}=V_{s a}-V_{s b} \cos 60-V_{s c} \cos 60$

$V_{q}=V_{s b} \cos 30-V_{s c} \cos 30$

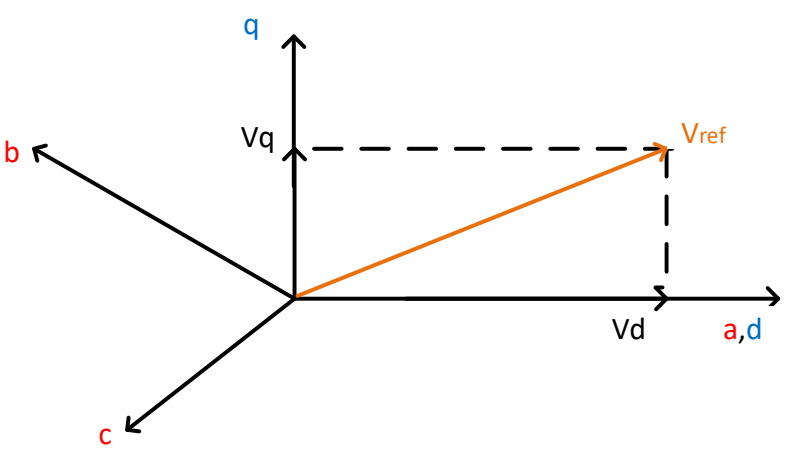

Figure 1. Voltage d-q coordinates.

(1) and (2) are written in the form of matrix in (3).

$\left[\begin{array}{l}V_{d} \\ V_{q}\end{array}\right]=\frac{2}{3}\left[\begin{array}{ccc}1 & -\frac{1}{2} & -\frac{1}{2} \\ 0 & -\frac{\sqrt{3}}{2} & -\frac{\sqrt{3}}{2}\end{array}\right]\left[\begin{array}{l}V_{s a} \\ V_{s b} \\ V_{s c}\end{array}\right]$

The magnitude $\overline{V_{\text {ref }}}$ and angle $\alpha$ of the rotating vector are calculated using (4) and (5) [24].

$\left|\overline{V_{\text {ref }}}\right|=\sqrt{V_{d}^{2}}+\sqrt{V_{q}^{2}}$

$\alpha=\tan ^{-1}\left(\frac{V_{q}}{V_{d}}\right)=\omega_{s} t=2 \pi f t$

Using the (6), (7) and (8), the time change between sectors 1 and $6\left(\mathrm{~S}_{1}-\mathrm{S}_{6}\right)$ is determined. The voltages are applied in the range of $T_{m}$ and $T_{m+1}$. The $V_{0}$ or $V_{7}$ vector is applied during $\mathrm{T}_{0}[25]$.

$$
\begin{aligned}
& T_{m}=T_{s} m \frac{\sqrt{3}}{2} \sin \left(\frac{n}{3} \pi-\alpha\right) \\
& T_{m+1}=T_{s} m \frac{\sqrt{3}}{2} \sin \left(\alpha-\frac{n-1}{3} \pi\right) \\
& T_{0}=T_{s}-T_{1}-T_{2}
\end{aligned}
$$

When the output voltage is examined for the $\mathrm{T}$ period and the $V_{\text {ref }}$ voltage vector is examined in the $d-q$ axis, a total of 6 space vectors are obtained. These vectors are placed in the axis tool at 600 intervals. Switching states are variable in each region. The switching states for sector 1 and sector 4 are shown in Figure 2. The carrier and reference signals are not required in the space vector-PWM technique, like in the sinusoidal-PWM technique.
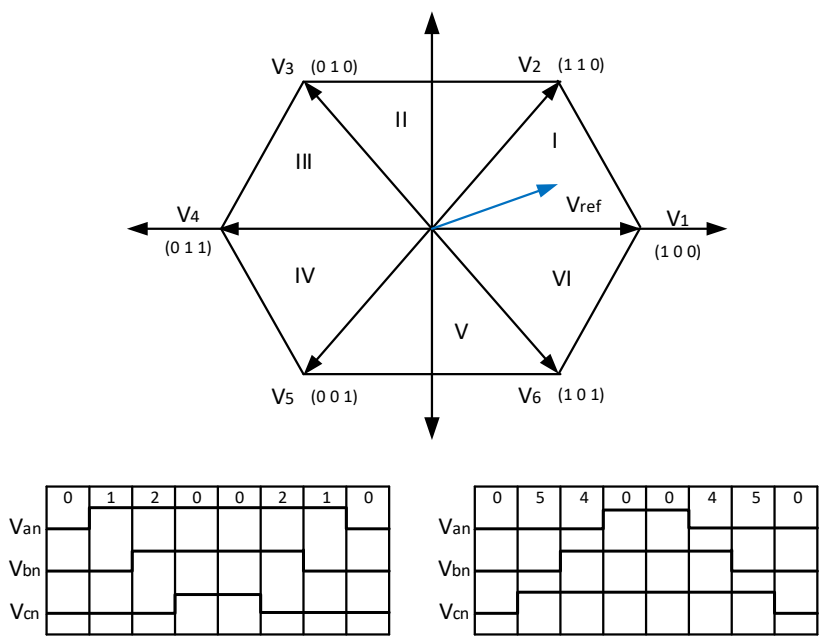

Figure 2. Sectors and switching states of space vectorPWM

\subsection{Moving Average Filter MAF}

The MAF filter is an easy-to-apply filter that can eliminate frequencies greater than the critical frequency of the filter. The critical frequency is calculated as the inverse of the fundamental frequency. In addition, the proposed filter improves the filter response. The output function of the proposed filter is created by Eq. (9). $n$ indicates the number of sample used to subtract average amounts [21].

$H(z)=n^{-1}\left(1+\frac{1}{z^{1}}+\frac{1}{z^{2}}+\cdots+\frac{1}{z^{n-1}}\right)=\frac{1}{n} \frac{1-z^{-n}}{1-z^{-1}}$

Figure 3 shows the structure of the MAF. It is supposed that even harmonics do not occur in voltage or current signals. The proposed filter includes integral receiver, signal delay, subtract and division blocks. The integral of the current or voltage signal is obtained using the integral receiver block. The delay block ensures that the 
current or voltage signal is delayed by $T / n$ of the basic period. The signals from the delay block output and the integrated receiver block output are subtracted in the subtract block. The resulting signal is sent to the division block and divided by $T / n$. As a result, the moving average of the current or voltage signal is obtained from Eq. (10)or Eq. (11) [22].

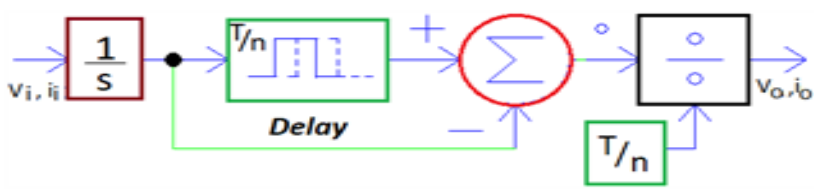

Figure 3. MAF control block

$$
\begin{aligned}
& M A F_{\text {out }, V d}=\frac{n}{T} \int_{t-\frac{T}{n}}^{t} V_{d} d t \\
& \text { MAF }_{\text {out }, \mathrm{i}_{\mathrm{d}}}=\frac{\mathrm{n}}{\mathrm{T}} \int_{\mathrm{t}-\frac{\mathrm{T}}{\mathrm{n}}}^{\mathrm{t}} \mathrm{i}_{\mathrm{d}} \mathrm{dt}
\end{aligned}
$$

Where $V_{d}$ is the $\mathrm{d}$ value of the source voltage signal and $i_{d}$ is the $\mathrm{d}$ value of the source current signal.

\subsection{PV-UPQC System Configuration}

PV-UPQC is a special power device used to reduce power quality problems in current and voltage in low power. The serial-APF (S-APF), parallel-APF (P-APF) and DC source fed PV panel are used together in the three-phase PV-UPQC system as shown in Figure 4 [13].

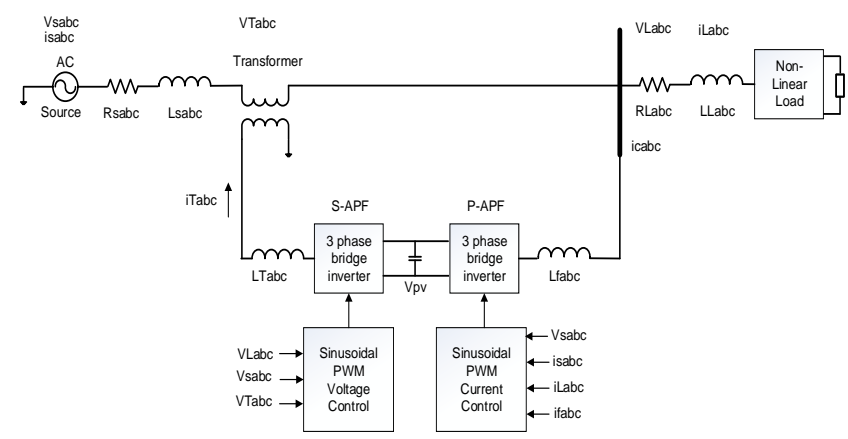

Figure 4. The topology of a three phase UPQC

The PV-UPQC contains of two voltage source inverters, a common DC source fed PV. The first of these inverters is the S-APF used to reduce voltage sag/swell, voltage unbalance and harmonic problems using DC voltage obtained from PV panel and the other inverter is P-APF used to increase the power factor and reduce odd harmonics in the source current using DC voltage obtained from PV panel. The PV panel produces electrical energy using solar energy. A PV panel is modeled by a current source, parallel connected diode, a series resistor and a parallel resistor. The equivalent circuit of the PV panel is shown in Figure 5 [26].

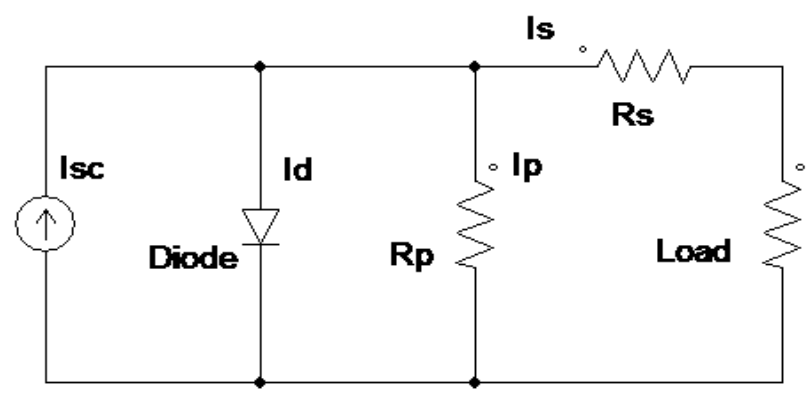

Figure 5. The power circuit of PV panel [26].

Where $R_{\mathrm{s}}$ is the series resistance and $R_{\mathrm{p}}$ is the shunt resistance. $\mathrm{D}$ is the ideal diode, $I_{\mathrm{p}}$ is the photo current source generated by the surface temperature and isolation. $V_{\text {out }}$ and $I_{\text {out }}$ represent the output voltage and output current of PV cell, respectively. The output current as a function of the PV output voltage is calculated by Eq. (12).

$I_{\text {out }}\left(1+\frac{R_{S}}{R_{\text {sh }}}\right)=n_{p} I_{\text {ph }}-n_{p} I_{\text {sat }}\left(e^{\frac{q\left(\left(\frac{V_{\text {out }}}{n_{S}}\right)+R_{\text {S.I }} \text { out }\right)}{A K T}}-1\right)-$
$-\frac{V_{\text {out }}-n_{S}}{R_{\text {sh }}}$

$-\frac{V_{o u t}-n_{S}}{R_{s h}}$

Where $q$ is elementary charge $(1.602176565 \times 10-19), K$ is the Boltzmann's constant $(1.38 \times 10-23 \mathrm{~J} / \mathrm{K}), n_{s}$ is the number of series cells and $n_{p}$ is the number of parallel cells. The cell saturation current shown in Eq. (13).

$I_{s a t}=I_{r r}\left(\frac{T}{T_{r}}\right)^{3} e^{\frac{q E g}{K A}\left(\frac{1}{T_{r}}-\frac{1}{T}\right)}$

Where $T$ is the temperature of the PV cell, $E_{g}$ is the band energy of each PV cell (1.12 eV for crystalline silicon), and $T_{r}$ is the reference temperature of PV cell. The $I_{p h}$ calculated by Eq. (14) represents the photon current.

$I_{p h}=\left\{I_{s s o}+k_{i}\left(T-T_{r}\right)\right\}\left(S_{i} / 1000\right)$

Where $I_{s s o}$ is the short-circuit current, $k_{i}$ the shortcircuit current temperature coefficient, and $S_{i}$ is the light intensity input solar radiation in $W / m^{2}$ and the reference temperature input is $25 \mathrm{C}^{\circ}$. The parameter of $\mathrm{PV}$ panel is given in Table 1 .

By using the DC-DC boost converter, the output voltage and power of the PV panel is increased. Changes in 
panel temperature and irradiation intensity affect the maximum power point. Loss of efficiency occurs when the power produced in PV systems does not match the load demand. It is important to operate the PV system at the maximum power point to prevent losses from the working point of the PV system. In the proposed system, P\&O algorithm, one of the maximum power point algorithms, is used to obtain maximum voltage and power from the PV panel. The purpose of the algorithm is to determine the $V_{m p p}$ and $I_{m p p}$ points where the PV system generates maximum power and to ensure that the system operates at this point. System output power is controlled after adjusting the voltage value of the PV system at certain intervals. It is decided to increase or decrease the voltage value in the next step according to the state of the output power [27]. Figure 6 shows block schema P\&O controller for PV panel.

Table 1. PV Panel Parameters

\begin{tabular}{|l|l|l|}
\hline \multicolumn{3}{|c|}{ PV Panel Parameters } \\
\hline Number of Cells & $\mathrm{Ns}$ & $72^{*} 7$ \\
\hline Light Intensity & $\mathrm{S}$ & $1000 \mathrm{~W} / \mathrm{m}^{2}$ \\
\hline Temperature & $\mathrm{T}$ & 25 \\
\hline Series Resistance & $\mathrm{R}_{\mathrm{s}}$ & $0.0075 / 4 \Omega$ \\
\hline Shunt Resistance & $\mathrm{R}_{\mathrm{sh}}$ & $1000 / 4 \Omega$ \\
\hline Short Circuit Current & $\mathrm{I}_{\mathrm{sc}}$ & $5.65 * 4 \mathrm{~A}$ \\
\hline Saturation Current & $\mathrm{I}_{\mathrm{s}}$ & $9.54 \mathrm{e}-9 * 4 \mathrm{~A}$ \\
\hline Band Energy & $\mathrm{E}_{\mathrm{g}}$ & 1.12 \\
\hline Ideality Factor & $\mathrm{A}$ & 1.2 \\
\hline Temperature Coefficient & $\mathrm{C}_{\mathrm{t}}$ & $0.002825^{*} 4$ \\
\hline Cofficient & $\mathrm{K}_{\mathrm{s}}$ & 0 \\
\hline
\end{tabular}

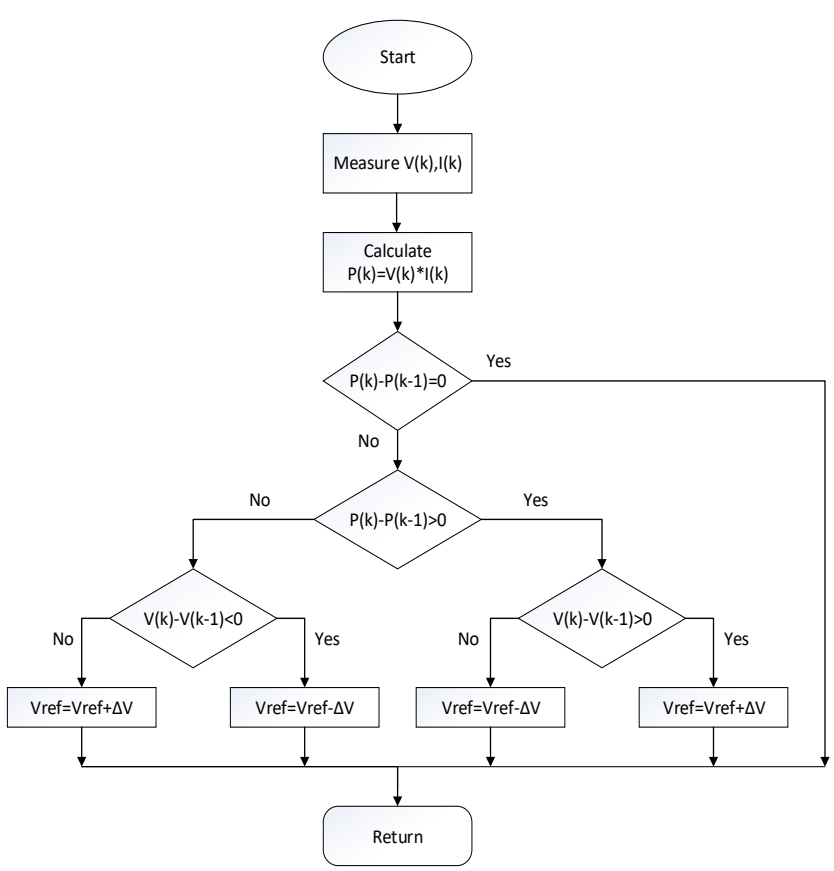

Figure 6. P\&O controller algorithm for PV panel

\subsection{Proposed Controller and Algorithm Schematic}

The conventional SRF-based control method is used in P-APF and S-APF in the literature [28]. In the conventional control method, measured $\mathrm{i}_{\text {Sabc }}, \mathrm{V}_{\mathrm{Sabc}}, \mathrm{i}_{\mathrm{Labc}}$, $\mathrm{i}_{\text {cabc }}$ and $\mathrm{V}_{\text {tabc }}$ values are used for PWM signals used in SAPF and P-APF. The LPF is used to obtained $i_{s d}^{\prime}$ value and $t$ PWM signals for S-APF and P-APF are obtained using sinusoidal-PWM in the literature. In the proposed control algorithm, ab two phase voltages, ab two phase currents, abc three load voltages and PV panel voltage are measured. In the proposed algorithm, the moving average filter increases the response speed of the classic low pass filter. Also, space vector-PWM technique improves the running-up and disconnect time of the active switches [11].

The algorithm used in the calculation of reference current and voltage using the proposed filter has advantages over other algorithms. The proposed algorithm is fast, it reaches steady state operation in a shorter time at balanced loads, it is not affected to voltage harmonics, requires simpler calculation. Eliminates harmonics that occur in unbalanced loads. It also improves PF. Figure 7 shows the block schema of new controller.

The theta angle is obtained using a phase locked loop. Figure 8 shows the PLL circuit used. The c phase voltage is calculated using by Eq. (15).

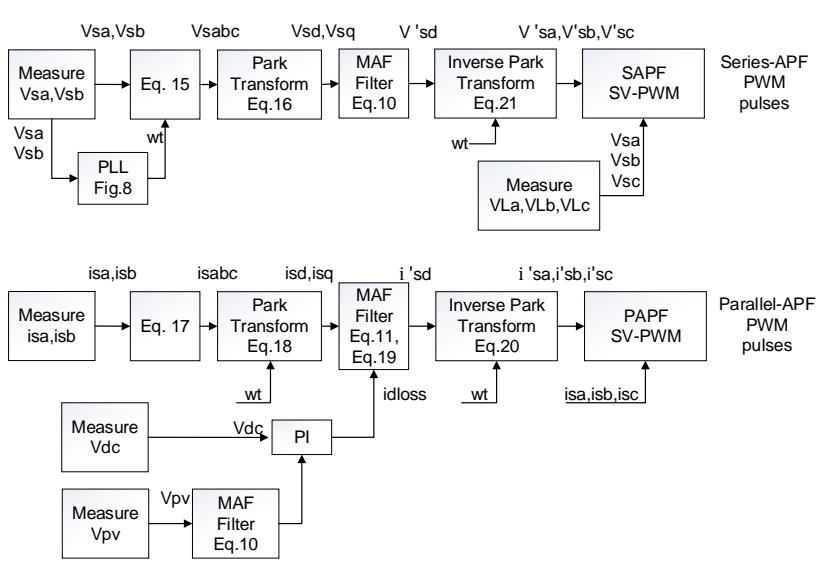

Figure 7. The algorithm scheme of proposed controller

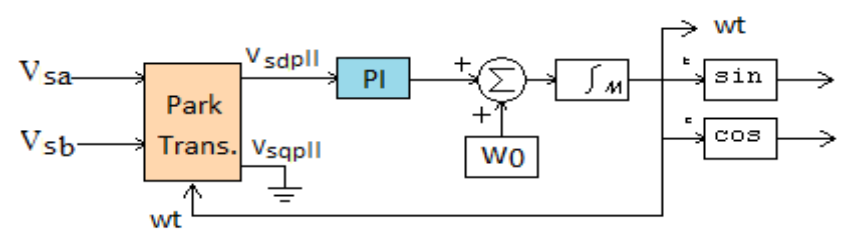

Figure 8. Phase locked loop circuit

$\mathrm{V}_{\mathrm{sc}}=-\mathrm{V}_{\mathrm{sa}}-\mathrm{V}_{\mathrm{sb}}$ 
The $d-q$ values $V_{d p l l}$ and $V_{q p l l}$ of the source abc voltages are obtained by using Eq. (16).

$\mathrm{v}_{\mathrm{d}}=\frac{2}{3}\left(\cos (\mathrm{wt}) \mathrm{v}_{\mathrm{sa}}+\cos \left(\mathrm{wt}-\frac{2 \pi}{3}\right) \mathrm{v}_{\mathrm{sb}}+\cos \left(\mathrm{wt}+\frac{2 \pi}{3}\right) \mathrm{v}_{\mathrm{sc}}\right)$

$\mathrm{v}_{\mathrm{q}}=\frac{2}{3}\left(-\sin (w \mathrm{t}) \mathrm{v}_{\mathrm{sa}}-\sin \left(\mathrm{wt}-\frac{2 \pi}{3}\right) \mathrm{v}_{\mathrm{sb}}-\sin \left(w \mathrm{t}+\frac{2 \pi}{3}\right) \mathrm{v}_{\mathrm{sc}}\right)$

$\mathrm{v}_{0}=\frac{2}{3}\left(\frac{1}{2} \mathrm{v}_{\mathrm{sa}}+\frac{1}{2} \mathrm{v}_{\mathrm{sb}}+\frac{1}{2} \mathrm{vs}_{\mathrm{c}}\right)$

The obtained $\mathrm{V}_{\text {dpll }}$ is applied to the proportional-integral controller. The proportional-integral controller output is summed with $\omega_{0}$. The obtained signal is integrated and $\omega t$ is obtained [17]. In the control algorithm used in P-APF, $i_{s a}$ and $i_{s b}$ currents are measured and $i_{s c}$ phase current is obtained from (17).

$\mathrm{i}_{\mathrm{sc}}=-\mathrm{i}_{\mathrm{sa}}-\mathrm{i}_{\mathrm{sb}}$

The $d-q$ values of the current are calculated from 3 phase currents using (18).

$i_{s d}=\frac{2}{3}\left(\cos (w t) i_{a}+\cos \left(w t-\frac{2 \pi}{3}\right) i_{s b}+\cos \left(w t+\frac{2 \pi}{3}\right) i_{s c}\right)$

$\mathrm{i}_{\mathrm{sq}}=\frac{2}{3}\left(\sin (w \mathrm{t}) \mathrm{i}_{\mathrm{sa}}+\sin \left(w \mathrm{t}-\frac{2 \pi}{3}\right) \mathrm{i}_{\mathrm{sb}}+\sin \left(w \mathrm{t}+\frac{2 \pi}{3}\right) \mathrm{i}_{\mathrm{sc}}\right)$

$i_{s 0}=\frac{2}{3}\left(\frac{1}{2} i_{s a}+\frac{1}{2} i_{s b}+\frac{1}{2} i_{s c}\right)$

The moving average filter is applied to the obtained $i_{d}$ value. By applying moving average filter to the measured DC voltage obtained PV panel, fluctuations in the voltage are eliminated. The filter output is compared with the desired DC voltage and passed through the controller. By collecting the lost current and MAF filter output, the reference $\mathrm{d}$ component of current is obtained using (19).

$\mathrm{i}_{\mathrm{sd}}^{\prime}=\mathrm{i}_{\mathrm{dloss}}+\operatorname{MAF}\left(\mathrm{i}_{\mathrm{sd}}\right)$

The reference abc currents are calculated from (20) using the obtained reference $d$ current and the $q$ component equal to 0 . The reference abc currents obtained are compared with the measured abc currents and signals are generated for the active switches via the space vector-PWM technique.

$\mathrm{i}_{\text {sa }}^{\prime}=\cos (w \mathrm{t}) \mathrm{i}^{\prime}{ }_{\text {sd }}+\sin (w \mathrm{t}) \mathrm{i}_{\text {sq }}^{\prime}+\mathrm{i}^{\prime}{ }_{s 0}$ $\mathrm{i}_{s b}^{\prime}=\cos \left(w t-\frac{2 \pi}{3}\right) \mathrm{i}^{\prime}{ }_{s d}+\sin \left(w t-\frac{2 \pi}{3}\right) \mathrm{i}_{\text {sq }}^{\prime}+\mathrm{i}_{\mathrm{s} 0}^{\prime}$

$\mathrm{i}^{\prime}{ }_{s c}=\cos \left(w t+\frac{2 \pi}{3}\right) \mathrm{i}^{\prime}{ }_{s d}+\sin \left(w t+\frac{2 \pi}{3}\right) \mathrm{i}^{\prime}{ }_{s q}+\mathrm{i}^{\prime}{ }_{s 0}$

In the S-APF, the moving average filter is applied to the obtained $V_{d}$ value of (16). The reference $d$ component of load voltage is obtained from MAF filter output. The reference abc load voltages are calculated from (21) using the obtained reference $d$ load voltage and the $\mathrm{q}$ component equal to 0 . The reference abc voltages obtained are compared with the measured abc load voltages and signals are generated for the active switches via the space vector-PWM technique.

$$
\begin{aligned}
& {v^{\prime}{ }_{L a}}^{\prime}=\cos (w t) V_{d}^{\prime}+\sin (w t) V_{q}^{\prime}+V_{0}^{\prime} \\
& v_{L b}^{\prime}=\cos \left(w t-\frac{2 \pi}{3}\right) V_{d}^{\prime}+\sin \left(w t-\frac{2 \pi}{3}\right) V_{q}^{\prime}+V_{0}^{\prime} \\
& {v_{L c}^{\prime}}^{\prime}=\cos \left(w t+\frac{2 \pi}{3}\right) V_{d}^{\prime}+\sin \left(w t+\frac{2 \pi}{3}\right) V_{q}^{\prime}+V_{0}^{\prime}
\end{aligned}
$$

\section{Simulation Study and Experimental Study}

The performance of the proposed algorithm is tested both by simulation studies using PSIM and experimental studies. Three phase thyristor rectifier is used as nonlinear load. Sampling time for simulation study is $0.5 \mathrm{e}-6 \mathrm{~s}$. Figure 9 shows the simulation scheme of the power circuit and control algorithm created for the three-phase PV-UPQC. Simulation parameters are given in Table 2.

$\mathrm{S}-\mathrm{APF}$ is connected in series with the system through transformer to eliminate voltage problems in the grid and generate sinusoidal voltage. In the S-APF, 3 singlephase transformers with a conversion ratio of 270 / 90V and 5,4KVA are used. The obtained reference abc voltages are compared with the sensed source abc voltages. The P-APF is operated as a closed-loop controller by generating the reference filter currents to correct events that cause power quality problems related to nonlinear loads by continuously reading the grid or load currents according to the control algorithm used. The DC voltage generated from PV panel must be maintained at a desired value. The reference value must be removed from the PV panel voltage, the fault must be reduced to zero with a transfer function and added to the active current of the control signal.

Simulation studies to verify the performance of the proposed controller have been tested with the PSIM software program. $V_{\text {sab }}$ represents for phase to phase voltage and its value is $190 \mathrm{~V}$. The RMS value of the phase voltage $\mathrm{V}_{\mathrm{sa}}$ is $120 \mathrm{~V}$. 


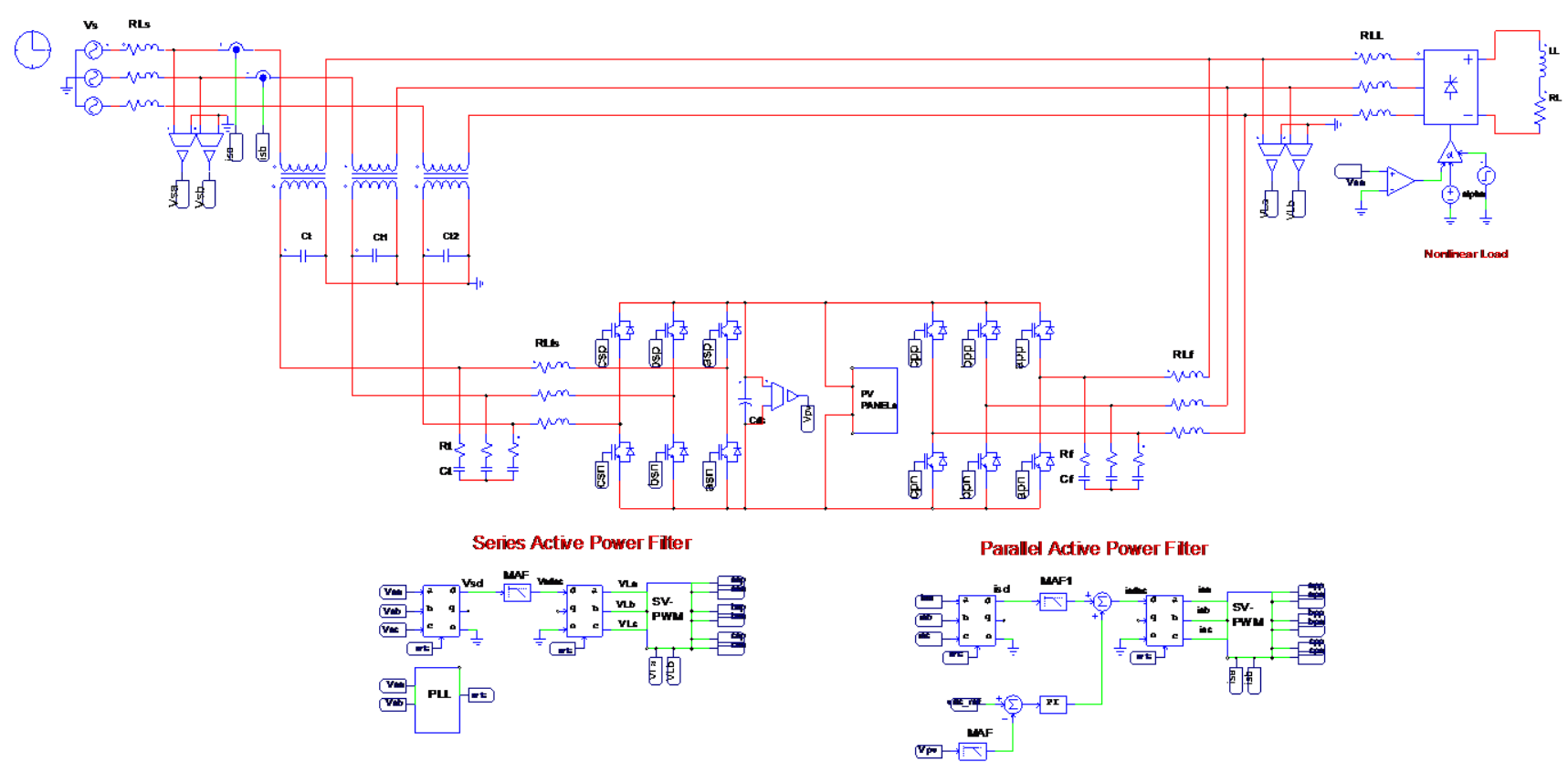

Figure 9. Simulation model of three-phase UPQC

Table 2. Simulation parameters

\begin{tabular}{|c|c|}
\hline \multicolumn{2}{|l|}{ Source } \\
\hline $\mathrm{V}_{\mathrm{sab}}$ & 190Vrms \\
\hline$f$ & $50 \mathrm{~Hz}$ \\
\hline $\mathrm{R}_{\mathrm{sabc}}$ & $10 \mathrm{~m} \Omega$ \\
\hline $\mathrm{L}_{\mathrm{sabc}}$ & $0.1 \mathrm{mH}$ \\
\hline \multicolumn{2}{|l|}{ Load } \\
\hline $\mathrm{R}_{\mathrm{sabc}}$ & $0.25 \Omega$ \\
\hline $\mathrm{L}_{\mathrm{sabc}}$ & $1.47 \mathrm{mH}$ \\
\hline $\mathrm{R}_{\mathrm{L}}$ & $30 \Omega$ \\
\hline $\mathrm{LL}_{\mathrm{L}}$ & $11.53 \mathrm{mH}$ \\
\hline P-APF & S-APF \\
\hline $\mathrm{Rp}_{\text {Fabc: }}: 0.6 \mathrm{~m} \Omega$ & $\mathrm{Rs}_{\mathrm{Fabc}}: 0.65 \mathrm{~m} \Omega$ \\
\hline Lp Fabc: $3.5 \mathrm{mH}$ & LSFabc:3mH \\
\hline fргжм:15kHz & fSPwм:18kHz \\
\hline $\mathrm{C}_{1}$ & $2350 \mu \mathrm{F}$ \\
\hline $\mathrm{V}_{\mathrm{dc}}$ & $400 \mathrm{~V}$ \\
\hline
\end{tabular}

RC filters are used as switching filter element in power circuit of S-APF and P-APF. The RC filter works as a second-order low-pass passive filter and is used to filter high frequency switching voltages at the output of the voltage source inverter. Resonance frequency occurs when switching voltages are not sufficiently filtered. The required filtering is set by $\mathrm{RC}$. As the value of $\mathrm{R}$ in the RC filter element decreases, the IGBT switching frequency decreases. Different R values were used in the RC filter element in simulation circuit. For this, the switching frequencies are different for SAPF and PAPF.

The source voltage harmonics of $15.81 \%$ are reduced to $0.57 \%$ and the source current harmonics of $26.31 \%$ is reduced to $0.45 \%$ after applying the proposed controller for three PV-UPQC system with balanced nonlinear RL load, as given in Figure 10. The THD value is below the harmonic limits given in IEEE 519-1992 standard. As given in Figure 11, the THD values of source voltages are reduced from $15.80 \%$ to $0.57 \%$ and the THD values source currents are reduced from $27.73 \%$ to $0.42 \%$ after applying the proposed controller for three PVUPQC system with balanced nonlinear RC load.
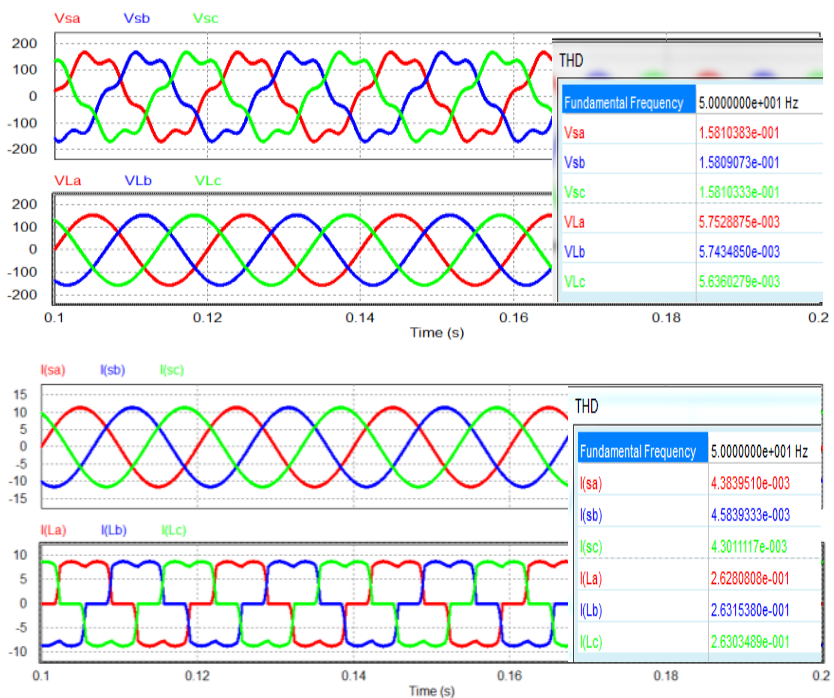

Figure 10. The effect of S-APF and P-APF when the proposed control algorithm is studied with RL load.

Figure 12 shows the PF value of the voltage and current signal obtained before and after the PV-UPQC system starts up. The PF value measured from the signals obtained using the proposed algorithm is 0.9877. This value shows that the new algorithm improves the PF value. 


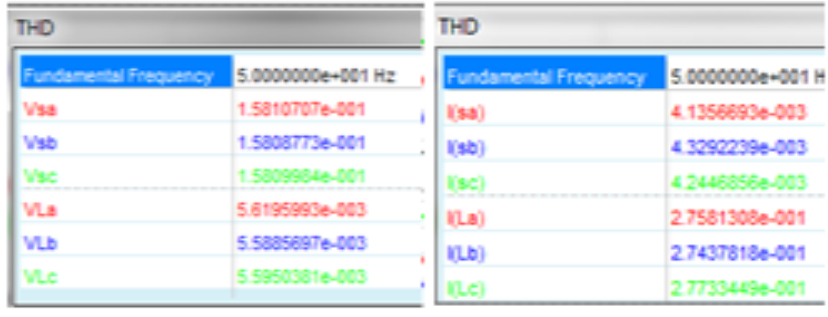

Figure 11. The THD values of source voltages and currents for balanced nonlinear RC load.
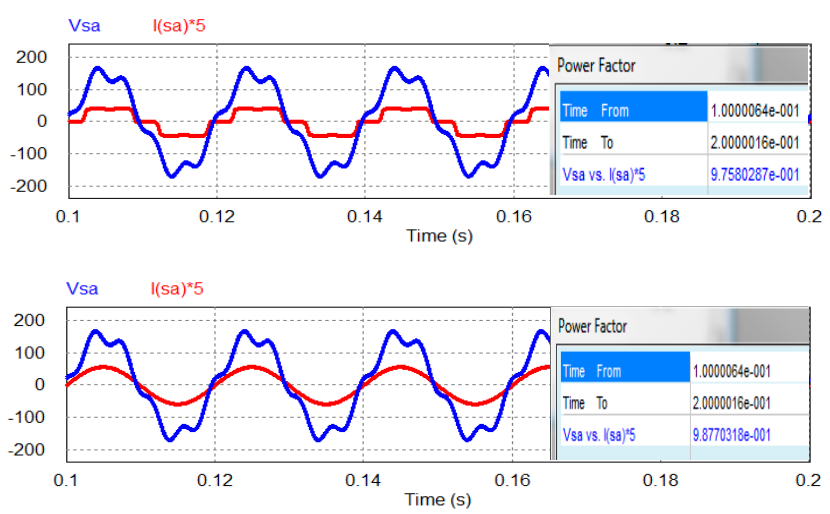

Figure 12. The power factor value of the source voltage and current signal before and after applying controller

The study of the proposed controller is tested when the unbalanced nonlinear load is connected. As given in Figure 13, the unbalanced of the source and load voltages are $20 \%$ before applying the proposed controller and the unbalance in the load voltage has eliminated after applying the proposed controller for unbalanced nonlinear load. Figure 13 illustrates the abc load voltages without unbalance and perfectly maintained with proposed controller.
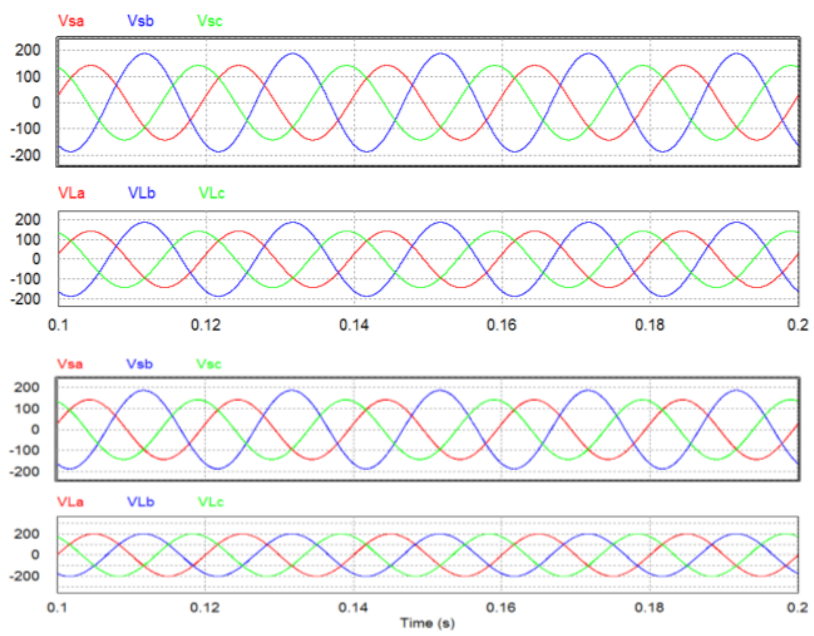

Figure 13. The abc source and load voltages signals obtained before and after applying the proposed controller with unbalanced nonlinear load.
Figure 14 shows the $i_{s a}, i_{s b}, i_{s c}$ source current signals , the $\mathrm{i}_{\mathrm{La}}, \mathrm{i}_{\mathrm{Lb}}, \mathrm{i}_{\mathrm{Lc}}$ load currents signals before and after applying the proposed controller for three PV-UPQC system with unbalanced nonlinear load. The unbalanced of the currents is $27 \%$ and the current harmonic is $33.47 \%$. As clearly shown in Figure 14, the unbalance of the currents is reduced and the THD of the currents is reduced to $0.60 \%$ using proposed controller.
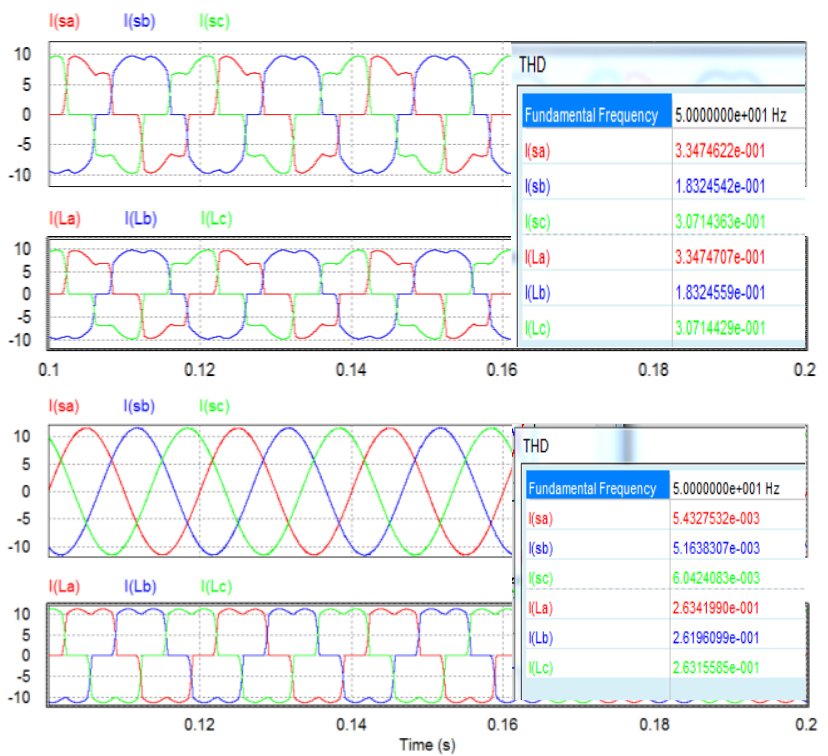

Figure 14. The abc source and load currents signals obtained a)before and b) after applying the proposed controller with unbalanced nonlinear load

The proposed controller is analyzed under steady and transient study. Figure 15 shows the $V_{s a}, V_{s b}, V_{s c}$ source voltage signals, $\mathrm{V}_{\mathrm{La}}, \mathrm{V}_{\mathrm{Lb}}, \mathrm{V}_{\mathrm{Lc}}$ load voltage signals, $\mathrm{i}_{\mathrm{La}}, \mathrm{i}_{\mathrm{Lb}}, \mathrm{i}_{\mathrm{Lc}}$ load current signals, $\mathrm{i}_{\mathrm{sa}}, \mathrm{i}_{\mathrm{sb}}, \mathrm{i}_{\mathrm{sc}}$ source current signals for transient study when the PV-UPQC system is activated at $\mathrm{t}=0.15 \mathrm{~ms}$. The algorithm used in the calculation of reference current and voltage using the proposed filter has advantages over other algorithms. Although the cutoff frequency of the low pass filter is as low as $10 \mathrm{~Hz}$, some ripples can be observed in the filter output. However, the component filtered using the MAF achieves steady-state study faster due to its very good attenuation and improved dynamic response [22].

As it can be seen in Figure 15, the proposed algorithm is fast since it reaches steady state operation from transient operation in a short time at balanced loads. It is not affected by voltage harmonics and requires simpler calculation. Eliminates harmonics that occur in unbalanced loads. It can be applied easily in the digital implementation.

Figure 16 shows the steady response of the controller for PV-UPQC system after applying proposed controller. In the Figure 16 , the $V_{s a}, V_{s b}$ and $V_{s c}$ are source voltage 
signals, the $\mathrm{V}_{\mathrm{ta}}, \mathrm{V}_{\mathrm{tb}}$ and $\mathrm{V}_{\mathrm{tc}}$ are transformer voltage signals, the $\mathrm{V}_{\mathrm{La}}, \mathrm{V}_{\mathrm{Lb}}, \mathrm{V}_{\mathrm{Lc}}$ are load voltage signals, the $\mathrm{i}_{\mathrm{La}}$, $\mathrm{i}_{\mathrm{Lb}}, \mathrm{i}_{\mathrm{Lc}}$ are load current signals, the $\mathrm{i}_{\mathrm{ca}}, \mathrm{i}_{\mathrm{cb}}, \mathrm{i}_{\mathrm{cc}}$ are compensator current signals, the $i_{s a}, i_{s b}, i_{s c}$ are source current signals, the $V_{d c}$ is voltage signal, the $v_{s a}$ is a phase voltage signal and the $\mathrm{i}_{\mathrm{La}} * 5$ is a phase current signal for power factor value.

In Table 3, the proposed control algorithm results are compared with other algorithms. In the results obtained, the harmonic in voltage is reduced from
$15.81 \%$ to $1.98 \%$ and the harmonic in current is decreased from $26.27 \%$ to $2.38 \%$ when using the traditional SRF algorithm, and harmonic in voltage is reduced from $15.81 \%$ to $0.57 \%$ and harmonic in current is decreased from $26.27 \%$ to $0.45 \%$ when using the proposed control algorithm. Using the proposed control algorithm, harmonics in current and voltage are reduced. These simulation results show that the harmonic elimination of PV-UPQC can be done effectively.

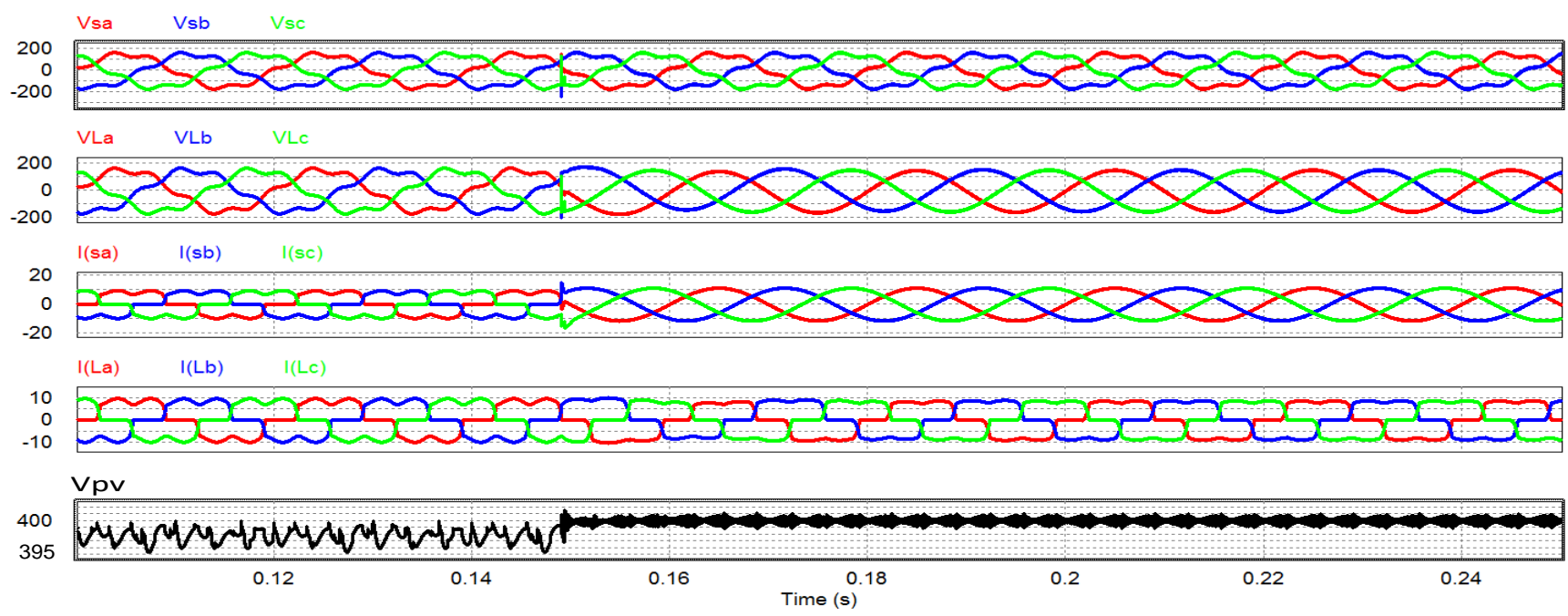

Figure 15. The transient response for operation of PV-UPQC

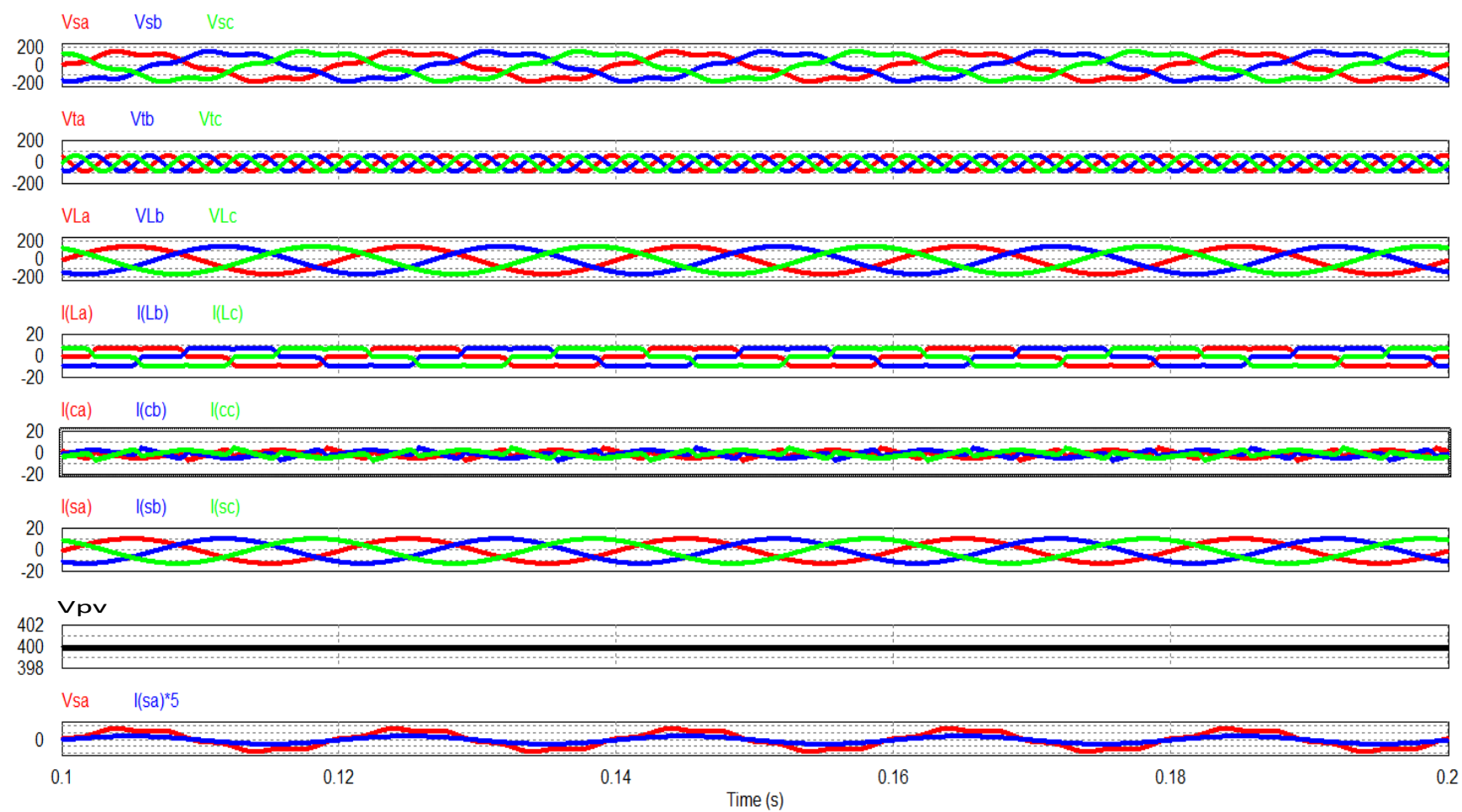

Figure 16. The steady state response of the controller for operation of PV-UPQC system after applying proposed controller 
Table 3. The comparison of the proposed control algorithm and the algorithms in the literature

\begin{tabular}{|c|c|c|c|c|}
\hline \multirow{2}{*}{$\begin{array}{c}\text { PV-UPQC control } \\
\text { algorithms }\end{array}$} & \multicolumn{2}{|c|}{$\begin{array}{r}\text { Without filter } \\
\text { THD(\%) }\end{array}$} & \multicolumn{2}{c|}{ With filter THD(\%) } \\
\cline { 2 - 5 } & Voltage & Current & Voltage & Current \\
\hline $\begin{array}{c}\text { DQ Fuzzy logic } \\
\text { method[22] }\end{array}$ & $25.38 \%$ & $28.28 \%$ & $3.75 \%$ & $3.25 \%$ \\
\hline ISCT method[15] & $5.38 \%$ & $15.10 \%$ & 2.47 & $4.36 \%$ \\
\hline PQ method & $15.81 \%$ & $26.27 \%$ & $2.84 \%$ & $4.16 \%$ \\
\hline $\begin{array}{c}\text { Conventional } \\
\text { SRF method }\end{array}$ & $15.81 \%$ & $26.27 \%$ & $1.98 \%$ & $2.38 \%$ \\
\hline $\begin{array}{c}\text { Proposed MAF } \\
\text { and SV-PWM }\end{array}$ & $15.81 \%$ & $26.27 \%$ & $\mathbf{0 . 5 7} \%$ & $\mathbf{0 . 4 5} \%$ \\
\hline
\end{tabular}

The experimental prototype in the three phase PV-UPQC system consists of two controlled inverters (S-APF and P-APF). The three-phase source voltage is $190 \mathrm{~V}$ and the source frequency is $50 \mathrm{~Hz}$. The DC bus links of both shunt and series APFs are connected to a $2200 \mu \mathrm{F}$ DC capacitor. A three-phase thyristor rectifier are used as nonlinear loads. The values of the components used in the experimental study are given in Table II. The DC bus voltage and source currents after applying proposed control algorithm are shown in Figure 17.

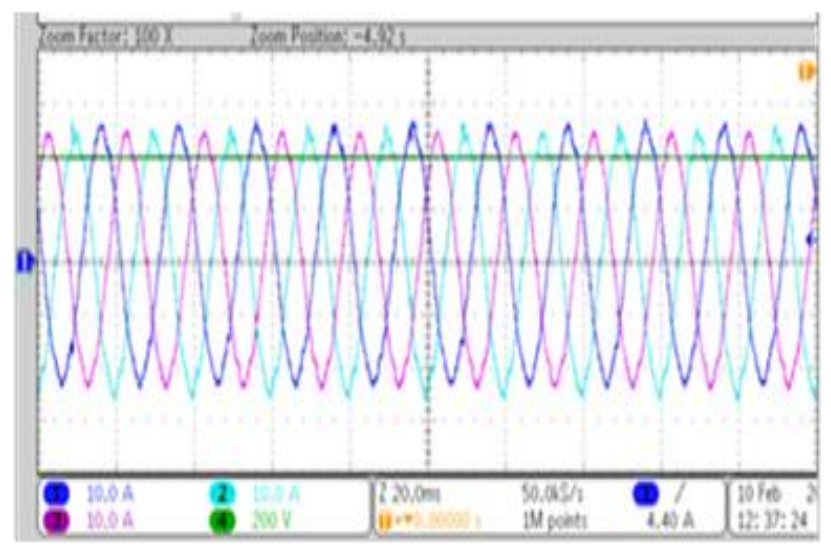

Figure 17. Experimental results for DC voltage and source currents after

The source currents before and after load variation are shown in Figure 18. Using the proposed control algorithm, harmonics in current and voltage are reduced. These experimental results show that the harmonic elimination of PV-UPQC can be done effectively. The proposed algorithm reaches steady state operation in a shorter time compared to the low pass filter for balanced loads.

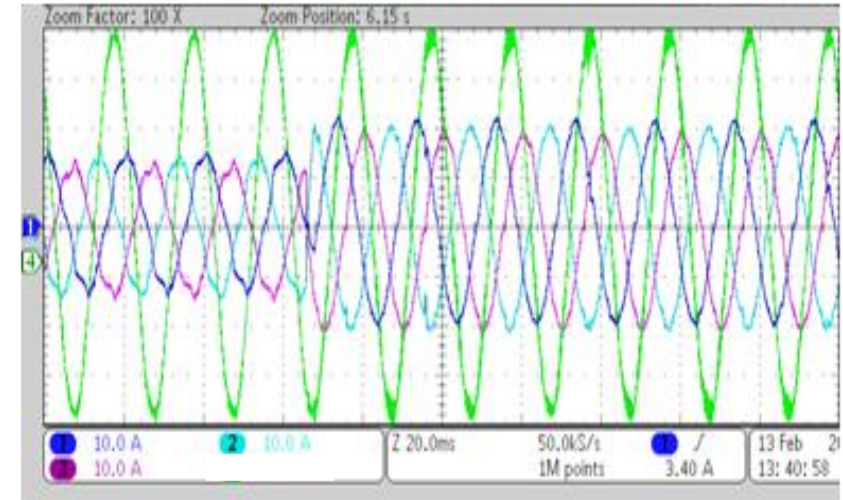

Figure 18. Experimental results after load variation

\section{Conclusions and Future Study}

In this study, a new SRF based controller is proposed to generate reference current and voltage signals using mobile average filter and space vector-PWM to improve the power quality of the energy system. In the controller used in P-APF, only ab source currents are measured and c source current is calculated using two measured currents. MAF filter is used to obtain the reference current signals. The switching signals are obtained using space vector-PWM technique. In the controller used in S-APF, only ab source voltages are measured and c source voltage is calculated using two measured currents. MAF filter is used to obtain the reference load voltage signals. The switching signals are obtained using space vector-PWM technique.

The proposed control algorithm improves power factor, improves simultaneous voltage and current quality, reduces total harmonic distortion, reduces source current harmonic and load voltage harmonic, reduced the numbers of measurements in system. According to the results obtained, the lowest THD value is obtained in current and voltage using the proposed algorithm. When the results obtained are examined, the proposed controller for three-phase PV-UPQC gives better results than the traditional SRF based controller in attenuation of harmonics in current and voltage and in increasing the power factor.

As future study, the machine learning and deep learning algorithms to be used to switching inverters in P-APF and S-APFs are investigated in order to reduce the noise injected into the grid and contained in parallel filter current and series filter voltage.

\section{References}

[1] Ram, J.P., Rajasekar, N. and Miyatake, M., "Design and overview of maximum power point tracking techniques in wind and solar photovoltaic systems: A review", Renewable and Sustainable Energy Reviews, Vol.73, 11381159, 2017.

[2] Brenna, M., Faranda, R. and Tironi, E. "A new proposal for power quality and custom power improvement: OPEN UPQC", IEEE T. Power Delivery, Vol.24, No.4, 2107-2116, 2009. 
[3] Dash, S.K. and Ray, P.K. "Design and analysis of grid connected photovoltaic fed unified power quality conditioner", International Journal of Emerging Electric Power Systems, Vol.17, No.3, 301-310, 2016.

[4] Devassy, S. and Singh, B. "Modified pq-theory-based control of solar-PV-integrated UPQC-S", IEEE T. Industry Applications, Vol.53, No.5, 5031-5040, 2017.

[5] Khadkikar, V. and Chandra, A. "A new control philosophy for a unified power quality conditioner (UPQC) to coordinate load-reactive power demand between shunt and series inverters", IEEE T. Power Delivery, Vol.23, No.4, 2522-2534, 2008.

[6] Akçay, M. T., and Arifoğlu, U., "Anlık Güç Kuramı ile Dengesiz Yükler İçin SAGF Uygulaması”, Haliç University, Journal of Science, Vol.2, No.1, 1-16, 2019.

[7] Akçay, M. T., and Kocaarslan, I., "1500 V DC Beslemeli Raylı Sistemlerde Gerilim Harmoniği Probleminin AGT Tabanlı Paralel Aktif Güç Fitresi ile Çözümü", International Journal of Advances in Engineering and Pure Sciences, Vol.32, No.4, 365-373, 2020.

[8] Cavalcanti, M.C., Azevedo, G.M.S., Amaral, B.A., Neves, F.A.S., "A photovoltaic generation system with unified power quality conditioner function", IEEE Annual Conference of Industrial Electronics Society, 2005, 750755.

[9] Dharmalingam, R., Dash, S.S., Senthilnathan, K., Mayilvaganan, A.B., and Chinnamuthu, S., "Power quality improvement by unified power quality conditioner based on CSC topology using synchronous reference frame theory", The Scientific World Journal, Vol.2014, 1-7, 2014.

[10] Kesler, M., and Ozdemir, E., "Synchronous-referenceframe-based control method for UPQC under unbalanced and distorted load conditions", IEEE T. Industrial Electronics, Vol.58, No.9, 3967-3975, 2010.

[11] Onal, Y., Ucgun, H., "Low Total Harmonic Distortion and High Power Factor in Parallel Active Power Filter", International Journal of Scientific and Technological Research, Vol.5, No.2, 52-62, 2019.

[12] Dash, S.K., and Ray, P.K., "Novel PV-tied UPQC topology based on a new model reference control scheme and integral plus sliding mode dc-link controller", International Transactions on Electrical Energy Systems, Vol.28, No.7, 1-26, 2018.

[13] Mesbahi, N., Ouari, A., Abdeslam, D.O., Djamah, T., and Omeiri, A., "Direct power control of shunt active filter using high selectivity filter (HSF) under distorted or unbalanced conditions", Electric Power Systems Research, No.108, 113-123, 2014.

[14] Rao, K., and Srikanth, K. S., "Improvement of power quality using fuzzy logic controller in grid connected photovoltaic cell using UPQC", International Journal of Power Electronics and Drive Systems, Vol.5, No1, 101-111, 2014.

[15] Pal, Y., Swarup, A., and Singh, B., "Star-hexagon transformer supported UPQC", International Journal of
Electrical and Electronics Engineering, Vol.5, No.1, pp.6368, 2011.

[16] Reisi, A. R., Moradi, M. H., and Showkati, H., "Combined photovoltaic and unified power quality controller to improve power quality", Solar Energy, Vol.88, 154-162. 2013.

[17] Khadkikar, V., Agarwal, P., Chandra, A., Barry, A., and Nguyen, T., "A simple new control technique for unified power quality conditioner (UPQC)", In: Proc. 11th IEEE ICHQP, 2004, 289-93.

[18] Bouzelata, Y., Kurt, E., Chenni, R., and Altın, N., "Design and simulation of a unified power quality conditioner fed by solar energy", International journal of hydrogen energy, Vol.40, No.44, 15267-15277, 2015.

[19] Cheung, V.S.P., Yeung, R.S.C., Chung, H.S.H., and Lo, A.W.L., "A transformer-less unified power quality conditioner with fast dynamic control", IEEE T. Power Electr., Vol.33, No.5, 3926-3937, 2017.

[20] Palanisamy, K., Kothari, D.P., Mishra, M.K., Meikandashivam, S., and Raglend, I.J., "Effective utilization of unified power quality conditioner for interconnecting PV modules with grid using power angle control method", International journal of electrical power \& energy systems, 48, 131-138, 2013.

[21] da Silva, S.A.O., and Negrão, F.A., "Single-phase to threephase unified power quality conditioner applied in singlewire earth return electric power distribution grids", IEEE T. Power Electr., Vol.33, No.5, 3950-3960, 2017.

[22] Devassy, S., and Singh, B., "Design and performance analysis of three-phase solar PV integrated UPQC", IEEE T. Industry Applications, Vol.54, No.1, 73-81, 2017.

[23] Badran, M.A., Tahir, A.M., and Faris, W.F., "Digital implementation of space vector pulse width modulation technique using 8-bit microcontroller", World Applied Sciences Journal, Vol.21, 21-28, 2013.

[24] Celanovic, N., Boroyevich, D., "A fast space-vector modulation algorithm for multilevel three-phase converters", IEEE transactions on industry applications, Vol.37, No.2, 637-641, 2001.

[25] Shankar, M., Monisha, S., Shesna, H., Vignesh, T., Sikkandar, N., Sundaramoorthi, S., and Venkatesh, S., "Implementation of space vector pulse width modulation technique with genetic algorithm to optimize unified power quality conditioner", American Journal of Applied Sciences, Vol.11, No.1, 152-159, 2014

[26] Villalva, M.G., Gazoli, J.R., and Ruppert, F.E., "Comprehensive approach to modeling and simulation of photovoltaic arrays", IEEE Transactions on power electronics, Vol.24, No.5, 1198-1208, 2009.

[27] Kota, V.R., and Bhukya, M.N., "A novel linear tangents based P\&O scheme for MPPT of a PV system", Renewable and Sustainable Energy Reviews, Vol.71, 257-267, 2017.

[28] Monteiro, L.F., Aredes, M., and Neto, J.M., "A control strategy for unified power quality conditioner", IEEE International Symposium on Industrial Electronics, Vol.1, 391-396, 2003. 